\title{
Milk and Dairy Products and Their Nutritional Contribution to the Average Polish Diet
}

\author{
Hanna Górska-Warsewicz *®), Krystyna Rejman $『$, Wacław Laskowski® and \\ Maksymilian Czeczotko \\ Department of Organization and Consumption Economics, Faculty of Human Nutrition and Consumer Sciences, \\ Warsaw University of Life Sciences, 02-787 Warsaw, Poland \\ * Correspondence: hanna_gorska_warsewicz@sggw.pl
}

Received: 8 July 2019; Accepted: 30 July 2019; Published: 1 August 2019

check for updates

\begin{abstract}
The main aim of this study was to identify the dairy sources of energy and 44 nutrients in the average Polish diet. Our research included: carbohydrates, protein, total fat, saturated fatty acids (SFA), monounsaturated fatty acids (MUFA), polyunsaturated fatty acids (PUFA), cholesterol, 18 amino acids, 9 minerals, and 10 vitamins. The analysis was conducted based on the data from the 2016 Household Budget Survey, a representative sample of the Polish population (i.e., 36,886 households). The category of milk and dairy products was divided into three main groups (i.e., milk, cheeses, and yoghurts, milk drinks and other dairy products) and seven sub-groups (i.e., whole milk, reduced fat milk, condensed and powdered milk, ripened and melted cheese, cottage cheese, yoghurts, milk drinks and other dairy products). Milk and dairy products provided $9.1 \%$ of the total energy supply. A high share (above $20 \%$ ) in the supply of nutrients was noted in the case of calcium (54.7\%), riboflavin (28.1\%), vitamin B12 (26.1\%), and phosphorus (24.6\%). Supply at the level of 10-20\% was observed for protein, SFA, zinc, total fat, cholesterol, potassium, magnesium, and vitamin A. Of the amino acids, the share above $20 \%$ from dairy category was recorded in the case of 6 amino acids (proline, tyrosine, serine, lysine, valine, and leucine) and at the level of $10-20 \%$ for 10 amino acids (isoleucine, histidine, threonine, tryptophan, phenylalanine, methionine, glutamic acid, aspartic acid, alanine, and arginine).
\end{abstract}

Keywords: milk; dairy products; energy intake; nutrient intake; food sources

\section{Introduction}

Milk has been known as nature's most complete food [1] for millennia, playing currently an important role in the diet of over 6 billion people in the world [2-4]. Bovine milk predominates (83\%) in global milk production, which has increased over three decades by ca. $60 \%$, from 522 million tons to 828 million tons in 1987-2017 [5], in order to meet the growing demand for dairy products. According to Organization for Economic Cooperation and Development (OECD) and Food and Agriculture Organization (FAO) projections, the milk and dairy product consumption level per capita (in milk equivalent) in the coming years should remain very high in western countries in the regions of Europe and North America, while a significant increase is shown in North African countries, the Middle East and an exceptional rise in Asia zone countries and the East. A considerable rise in demand in central and east European Union countries (new member states of the EU), in the United States and Russia is also predicted [6].

Milk and dairy products are nutrient-dense foods, supplying energy and high-quality protein with a range of essential micronutrients (especially calcium, magnesium, potassium, zinc, and phosphorus) in an easily absorbed form [7-13]. Milk minerals are crucial for human health and development as well as in dairy processes as cheese-making and for all traits involving salt-protein interactions [14]. They play 
a key role in healthy human nutrition and development throughout life, but especially in childhood [7]. Dairy products are rich in nutrients that are essential for good bone health, including calcium, protein, vitamin D, potassium, and phosphorus [8]. Adequate calcium intake influences skeletal calcium retention during growth and thus affects peak bone mass achieved in early adulthood $[15,16]$. The high levels of calcium play an important role in the development, strength, and density of bones for children and in the prevention of bone loss and osteoporotic fractures in elderly people $[1,8,16]$. Studies show that frequent consumption of dairy foods and milk should be recommended in order to prevent periodontal disease [17-21]. Calcium also has been shown to be beneficial in reducing cholesterol absorption, and in controlling body weight and blood pressure [1].

There is no such unequivocal position regarding the effect of milk and dairy fat on human health. Currently controversy has emerged about the benefits compared with harms of dairy fat, including concerns over long-term effects [22]. The traditional diet-heart paradigm held that consumption of fat, and saturated fat in particular, raised levels of total and low-density lipoprotein (LDL) cholesterol leading to coronary heart disease. Following this knowledge dietary guidelines in many countries and of international authorities recommend consumption of low-fat dairy foods [7]. However recent studies show that milk and dairy products with high fat contents do not increase total and LDL cholesterol levels $[23,24]$, and whole milk significantly increases high-density lipoprotein HDL cholesterol concentrations compared to skimmed milk [24]. Most meta-analyses report no or weak inverse association between dairy intake, including butter, with cardiovascular disease and related intermediate outcomes [25-27]. However, some original studies indicate that saturated and trans fatty acids from dairy products were inversely associated with adiposity, diabetes and inflammatory outcomes, suggesting that dairy fat intake may have a beneficial effect on cardiovascular health $[22,26,28,29]$. Long-term cheese consumption is not associated with an increased risk of all-cause mortality [30] and even high consumption of dairy products, especially yogurt and cheese, may reduce the risk of overall and cardiovascular disease (CVD) mortality [31]. The relation between dairy product intake and the risk of ischemic heart disease remains controversial [28]. There is some suggestion that dairy consumption is inversely associated with stroke incidence [22,27].

As regards to type 2 diabetes, findings are inconsistent. Studies showed that higher intake of yogurt is associated with risk reduction of this disease [27,32,33], also a significant inverse association between intakes of dairy products, low-fat dairy products, and cheese and risk of type 2 diabetes was observed on the base of meta-analysis of 17 cohort studies [34]. On the other hand, findings indicated that consumption of total dairy are not beneficial in risk reduction of type 2 diabetes [32] and the associations varied both by dairy product and type and by baseline glycaemic status of the population [35].

Total dairy product intake has no significant impact on increased overall cancer mortality risk (results of meta-analysis study) [31,36] nor does the intake of individual dairy products [31], however a relationship existed between increase of whole milk intake and increase of prostate cancer mortality risk [36]. The Third Expert Report "Diet, Nutrition, Physical Activity and Cancer: a Global Perspective" [37] in a certain sense reflects this finding, showing that currently there is only limited evidence that dairy products (total dairy, milk, cheese and yogurt) and diets high in calcium increase risk of prostate cancer. According to these report findings, there is strong evidence that consuming dairy products (total dairy, milk, cheese and dietary calcium) decreases risk of colorectal cancer. This inverse association is largely attributed to high calcium content in milk and its products. In addition to calcium, lactic acid-producing bacteria may also protect against colorectal cancer, while the casein and lactose may increase calcium bioavailability. Other nutrients or bioactive constituents in dairy products, such as lactoferrin, vitamin D or the short-chain fatty acid butyrate may also impart their beneficial functions against colorectal cancer.

Aside from nutritional values of milk and dairy products their biologically active compounds (bioactive peptides, probiotic bacteria, antioxidants, vitamins, specific proteins, oligosaccharides, 
organic acids, highly absorbable calcium, conjugated linoleic acid and others) have crucial impacts on human functioning and health [1,25,38-44].

In terms of the importance of milk and dairy products, changes in food choice determinants and consumption patterns, the analysis of energy and nutrient sources in a given population is crucial to assure the adequate nutritional quality of diets. The aim of this study was to determine the role of milk and various types of dairy products as sources of energy and 44 nutrients in the average Polish diet based on data from the 2016 Household Budget Survey conducted by the Central Statistical Office on the representative sample of the Polish population.

\section{Methods}

\subsection{Study Overview}

Sources of energy and nutrients from milk and dairy products were analyzed. The 44 nutrients examined in this study included: carbohydrates, protein, 18 amino acids (leucine, isoleucine, valine, lysine, histidine, threonine, tryptophan, phenylalanine, methionine, cysteine, tyrosine, arginine, alanine, aspartic acid, glutamic acid, glycine, proline, and serine), total fat, fatty acids (saturated fatty acids, SFA; monounsaturated fatty acids, MUFA; polyunsaturated fatty acids, PUFA), cholesterol, 9 minerals (calcium, phosphorus, sodium, potassium, magnesium, iron, zinc, copper, iodine), and 10 vitamins (thiamin, riboflavin, niacin, vitamin B6, folate, vitamin B12, vitamin A, vitamin D, vitamin $\mathrm{E}$, and vitamin C).

The research process is presented in Table 1 and described in sub-chapters 2.2, 2.3 and 2.4.

Table 1. Research process.

\begin{tabular}{|c|c|}
\hline Stage & Description \\
\hline \multirow[t]{3}{*}{1.} & Two-stage random selection of representative sample of households (Central Statistical Office) \\
\hline & $\begin{array}{l}\text { a) Random selection of areas survey points based on the list of statistical regions developed in } \\
\text { Poland for National Census purposes }\end{array}$ \\
\hline & b) Random selection of households in every area survey point \\
\hline 2. & $\begin{array}{l}\text { Data base of 36,886 households (Central Statistical Office)-quantity of purchase and consumption } \\
\text { of food products in } 91 \text { sub-groups (in grams, kilograms, liters) per month in each household }\end{array}$ \\
\hline 3. & $\begin{array}{l}\text { Conversion of consumption into one person per month in each household (in grams, kilograms, } \\
\text { liters per person per month) - own calculations }\end{array}$ \\
\hline 4. & $\begin{array}{l}\text { Energy and nutrient content in consumed food products in } 91 \text { sub-groups in each household (in } \\
\mathrm{kcal}, \mathrm{g}, \mathrm{mg}, \mu \mathrm{g} \text { per day)—own calculations }\end{array}$ \\
\hline 5. & $\begin{array}{l}\text { Average energy and nutrient content in sub-groups in } \mathrm{kcal}, \mathrm{g}, \mathrm{mg}, \mu \mathrm{g} \text { per person per day in all } \\
\text { households-own calculations }\end{array}$ \\
\hline 6. & $\begin{array}{l}\text { Average energy and nutrient contribution (in \%) to the average Polish diet from each } \\
\text { sub-group-own calculations }\end{array}$ \\
\hline 7. & $\begin{array}{l}\text { Impact of socio-demographic and economic factors on the level and structure of energy and } \\
\text { nutrients supply from milk and dairy products-own calculations }\end{array}$ \\
\hline
\end{tabular}

\subsection{Sample Selection Method}

The Household Budget Survey (HBS) is a representative method of data collection in Poland organized and conducted by the Central Statistical Office, Social Surveys and Living Conditions Statistics Department. This survey is carried out annually on a sample of 36-39 thousand households. In this study, we used the 2016 data for 36,886 households (total number of persons: $n=99,230$ ) participating in the HBS [45]. Every year the research sample is selected randomly on the basis of a two-stage randomization system covering areas survey points, flats and households. This allows 
generalizing the received results for all households in Poland. Since 1993, the HBS has been conducted using a total monthly rotation [45-48].

In each household participating in the survey, the data of revenues, and consumption expressed in terms of quantity (in grams, kilograms, liters) and value (in Polish zloty PLN) are recorded in special budget book ("Household Budget Diary") for one month. Based on the HBS information on the number of persons in each household and the number of days of in-home nutrition, we calculated the consumption per one person per month for each household. We have received the amount of consumption expressed in grams, kilograms or liters per one person per month and day for each of 91 sub-groups.

Detailed information related to the sampling system, sample selection, research tools, and method of collecting information is provided in our previous studies [49-51].

\subsection{Food Grouping}

The HBS database contains the quantities of purchased and consumed food products from 91 food sub-groups (in grams, kilograms, liters) per month in each of 36,886 households. The classification of food products was developed based on a literature review [45,52-55], the specificity of products available on the Polish market [45,46] and was published in our earlier studies [49-51]. For the purpose of this study, we have included the dairy category "milk and dairy products" divided into three main groups and seven sub-groups (Table 2).

Table 2. Main groups and sub-groups in the category of milk and dairy products.

\begin{tabular}{cc}
\hline Main Groups & Sub-Groups \\
Milk & (1) whole milk \\
Cheeses and cottage cheeses & (2) reduced fat milk \\
condensed and powdered milk
\end{tabular}

\subsection{Statistical Analysis}

The next step was to convert the quantitative consumption of milk and dairy products (in grams, kilograms and liters) into the supply of energy and 44 nutrients to the diet in each household. This was the basis for calculating the average energy and nutrient supply for all households taking part in the HBS. For these calculations, we used current version of nutritional value tables, Nutritive Value Tables for Foods and Meals" (4th ed.) [56] as well as the R program (v 3.0.2) (Copyright (C) 2018, The R Foundation for Statistical Computing, Vienna, Austria), system and environment for statistical computation [57-59]. The weights of corrections were implemented to improve the representativeness of the results. It was possible due to a programming language with conditionals, loops, user defined recursive functions as well as a coherent, integrated tool collection for data analysis included in the $\mathrm{R}$ program [57,59]. This allowed us to consider the results as being representative for the Polish population [47,48]. We presented the results as a percentage supply of energy and 44 nutrients from the category "milk and dairy products". The details about this conversion are also included in our previous studies [49-51].

To analyze the impact of socio-demographic and economic factors on the level and structure of energy and nutrients supply from dairy category in the average diet, a cluster analysis as an exploratory tool [60-62] was applied. We included the level of the consumption of main dairy product groups to divide the sample population into clusters. In our calculations, the Neural Networks module in the Statistica 13.3 program (Copyright 1984-2017, TIBCO Software Inc., Palo Alto, CA, USA) and Kohonen 
Neural Network was applied [63]. The division into three clusters is characterized by an averaged correlation measure (correlation ratio) at a level of almost 0.5.

The identification of clusters was based on the following socio-demographic and economic features: age, sex, socio-economic affiliation/type of the households, education, income measured according to the quintile groups, assessment of the household's financial situation, assessment of nutrition, number of people in the household, number of inhabitants in the village, land use, family life phase, degree of urbanization, region, and study month. For each feature, the correlation table was created together with a measure of Cramer's correlation.

\section{Results}

Dairy sources of energy (Table 3) protein and amino acids (Table 4), carbohydrates, total fat, SFA, MUFA, PUFA and cholesterol (Table 5), minerals (Table 6), and vitamins (Table 7) are presented in the following sub-chapters.

\subsection{Milk and Dairy Products as Sources of Energy}

Energy contribution from milk and dairy products amounted to $9.1 \%$ (Table 3), which meant energy supply from dairy products at $205 \mathrm{kcal}$ in the average Polish diet providing $2261 \mathrm{kcal}$. The largest share in the energy supply was characterized by cheeses (including ripened, melted and cottage cheeses), followed by milk (in particular, whole fat milk).

Table 3. Dairy sources of energy contribution to the average Polish diet (in \% of total energy contribution).

\begin{tabular}{lc}
\hline & Energy \\
\cline { 2 - 2 } Contribution of Milk and Dairy Products in \%: & $\mathbf{9 . 0 7}$ \\
\hline Milk & 3.21 \\
whole milk & 2.21 \\
reduced fat milk & 0.91 \\
condensed and powdered milk & 0.09 \\
\hline Cheeses & $\mathbf{3 . 6 8}$ \\
ripened and melted cheeses & 2.53 \\
cottage cheeses & 1.15 \\
\hline Yoghurts, milk drinks and other dairy products & $\mathbf{2 . 1 7}$ \\
yoghurts & 0.58 \\
milk drinks and other dairy products & 1.59 \\
\hline
\end{tabular}

3.2. Milk and Dairy Products as Sources of Protein, Amino Acids, Carbohydrates, Total Fats, Fatty Acids, and Cholesterol

Milk and dairy products provided $18.1 \%$ of the daily total protein supply (Table 4 ). The supply of branched-chain amino acids (leucine, isoleucine and valine) from milk and its products developed at the level of $19-21 \%$. The remaining essential amino acids were supplied by milk and dairy products in an amount from $18.4 \%$ for methionine to $21.5 \%$ for lysine. In terms of the contribution of non-essential amino acids, differences in the supply of milk and dairy products from $7.8 \%$ (glycine) to $23.6 \%$ (tyrosine) were observed. The lowest supply of milk and dairy products was recorded for glycine $(7.8 \%$ of total supply) and cysteine ( $8.5 \%)$, the largest for tyrosine (23.6\%) and proline $(24.8 \%)$.

The structure of supply of particular amino acids indicates the significant position of cheeses. The cheeses were responsible for almost $9 \%$ of total protein supply. Considering branched-chain amino acids and other essential amino acids, the proportion of cheeses in the supply ranged from $8.6 \%$ (threonine) to $10.1 \%$ (valine). The second position was taken by milk, and the third-by milk drinks and other dairy products. 
Dairy sources of carbohydrates, total fat, fatty acids (SFA, MUFA, PUFA), and cholesterol are shown in Table 5. Milk and dairy products provided $11.3 \%$ of the total supply of total fat with a focus on SFA (18.4\%). The share of milk and dairy products in the supply of MUFA and PUFA was at $8.8 \%$ and $2.1 \%$ respectively. When analyzing product groups, the dominant share of cheeses in average supply of total fat (6\%) and SFA (9.9\%) should be indicated. The share of ripened and melted cheeses was at the level of $4.6 \%$ and $7.5 \%$, respectively. In the supply of cholesterol, the share of milk and dairy products was $11.6 \%$, of which almost half were cheeses $(5.7 \%)$. The category of dairy products was responsible for the supply of carbohydrates in 5\%. The most important ones were yoghurts, milk drinks and other dairy products $(2.4 \%)$, and milk $(2.3 \%)$.

\subsection{Milk and Dairy Products as Sources of Minerals and Vitamins}

Milk and dairy products are an important source of calcium, accounting for almost $55 \%$ of the supply of this mineral (Table 6). A large share was characterized by two product sub-groups: milk and cheese (each of these sub-groups provided over $20 \%$ of the total supply of this mineral). The supply of phosphorus from the category of milk and its products amounted to almost $25 \%$, of which cheese accounted for more than $10 \%$. The share of milk in the supply of phosphorus was at the level of $9.4 \%$. In the case of potassium, magnesium and zinc, the share of milk and its products in the average daily intake was in the range of $10-14 \%$. In the case of potassium and magnesium, milk predominated with a share of $6.8 \%$ in the case of potassium and $5.6 \%$ for magnesium, respectively. For the supply of zinc from milk and dairy products, cheese was the most important source of this mineral (6.7\% supply of this mineral in the average Polish diet). The remaining minerals were supplied by milk and its products at the level of $7-9 \%$.

The largest share of milk and its products in the supply of vitamins was recorded in the case of riboflavin and vitamin B12 (Table 7). In the structure of supply, the first place was for milk, providing $13.5 \%$ of the total supply of riboflavin and $10.3 \%$ of vitamin B12. The supply of vitamin A from the dairy category was at the level of $11 \%$, of which $5.2 \%$ constituted cheese, and $4.4 \%$-milk. The remaining vitamins were delivered by milk and its products at a level of less than $10 \%$. 
Table 4. Dairy sources of protein and amino acids contribution to the average Polish diet (in $\mathrm{g}$ and \%).

\begin{tabular}{|c|c|c|c|c|c|c|c|c|c|c|c|c|c|c|c|c|c|c|c|}
\hline Specification & 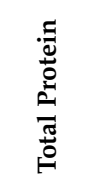 & 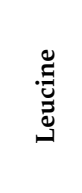 & 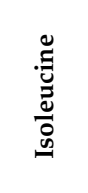 & 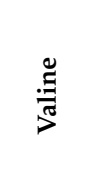 & 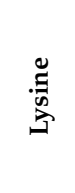 & 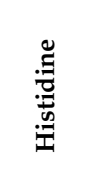 & 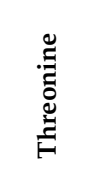 & 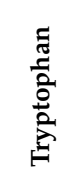 & 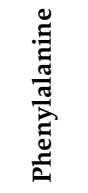 & 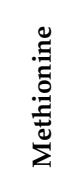 & 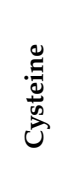 & 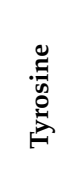 & 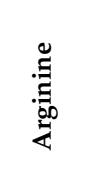 & $\begin{array}{l}\stackrel{\mathscr{\Xi}}{\Xi} \\
\stackrel{\Xi}{\rightleftarrows}\end{array}$ & 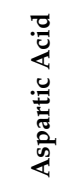 & 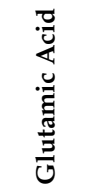 & $\frac{\mathscr{D}}{0}$ & $\frac{\mathscr{\Xi}}{\stackrel{\Xi}{2}}$ & 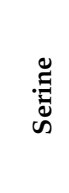 \\
\hline Average daily supply in $\mathrm{g}$ & 77.90 & 6.04 & 3.78 & 4.38 & 5.29 & 2.27 & 3.24 & 0.98 & 3.45 & 1.88 & 1.18 & 2.76 & 4.19 & 3.80 & 6.82 & 15.18 & 3.38 & 5.43 & 3.68 \\
\hline Contribution of milk and dairy in $\mathrm{g}$ & 14.07 & 1.21 & 0.72 & 0.91 & 1.14 & 0.39 & 0.57 & 0.18 & 0.66 & 0.35 & 0.10 & 0.65 & 0.48 & 0.45 & 0.97 & 2.88 & 0.26 & 1.35 & 0.78 \\
\hline Contribution of milk and dairy in \%: & 18.06 & 20.02 & 19.05 & 20.84 & 21.47 & 17.02 & 17.55 & 18.87 & 19.21 & 18.36 & 8.50 & 23.61 & 11.34 & 11.90 & 14.29 & 18.95 & 7.84 & 24.80 & 21.07 \\
\hline Milk & 5.43 & 6.15 & 6.28 & 6.52 & 7.42 & 5.02 & 5.19 & 5.37 & 5.66 & 5.58 & 2.81 & 6.16 & 3.40 & 3.84 & 4.49 & 5.31 & 2.27 & 7.23 & 6.35 \\
\hline whole milk & 3.41 & 3.87 & 3.93 & 4.10 & 4.47 & 3.15 & 3.28 & 3.39 & 3.53 & 3.49 & 1.76 & 3.92 & 2.13 & 2.44 & 2.75 & 3.29 & 1.36 & 4.56 & 4.07 \\
\hline reduced fat milk & 1.87 & 2.12 & 2.18 & 2.24 & 2.74 & 1.73 & 1.76 & 1.83 & 1.98 & 1.94 & 0.98 & 2.08 & 1.19 & 1.30 & 1.61 & 1.88 & 0.84 & 2.48 & 2.12 \\
\hline condensed and powdered milk & 0.15 & 0.16 & 0.17 & 0.17 & 0.21 & 0.14 & 0.14 & 0.14 & 0.15 & 0.15 & 0.08 & 0.16 & 0.09 & 0.10 & 0.13 & 0.15 & 0.07 & 0.19 & 0.16 \\
\hline Cheeses & 8.98 & 9.62 & 8.74 & 10.08 & 9.77 & 8.77 & 8.56 & 9.82 & 9.66 & 9.02 & 3.58 & 12.97 & 5.58 & 5.61 & 6.75 & 9.88 & 3.87 & 12.84 & 10.65 \\
\hline ripened and melted cheeses & 5.64 & 5.96 & 5.35 & 6.29 & 6.44 & 5.76 & 4.94 & 6.24 & 6.23 & 5.60 & 2.14 & 8.33 & 3.51 & 3.42 & 4.18 & 6.20 & 2.41 & 8.18 & 6.50 \\
\hline cottage cheeses & 3.34 & 3.67 & 3.39 & 3.79 & 3.33 & 3.00 & 3.62 & 3.58 & 3.43 & 3.42 & 1.44 & 4.64 & 2.07 & 2.19 & 2.57 & 3.68 & 1.46 & 4.65 & 4.16 \\
\hline $\begin{array}{l}\text { Yoghurts, milk drinks and other } \\
\text { dairy products }\end{array}$ & 3.65 & 4.24 & 4.03 & 4.25 & 4.28 & 3.23 & 3.81 & 3.69 & 3.89 & 3.76 & 2.12 & 4.49 & 2.36 & 2.46 & 3.05 & 3.76 & 1.70 & 4.74 & 4.07 \\
\hline yoghurts & 1.05 & 1.20 & 1.11 & 1.23 & 1.28 & 0.94 & 1.07 & 1.08 & 1.08 & 1.07 & 0.63 & 1.30 & 0.64 & 0.72 & 0.92 & 1.09 & 0.48 & 1.38 & 1.19 \\
\hline milk drinks and other dairy products & 2.60 & 3.04 & 2.92 & 3.02 & 3.00 & 2.28 & 2.74 & 2.61 & 2.81 & 2.69 & 1.49 & 3.19 & 1.72 & 1.74 & 2.14 & 2.68 & 1.22 & 3.36 & 2.88 \\
\hline
\end{tabular}


Table 5. Dairy sources of macronutrients contribution to the average Polish diet (in $\mathrm{g}$ or $\mathrm{mg}$ and \%).

\begin{tabular}{|c|c|c|c|c|c|c|}
\hline Specification & Carbohydrates & Total Fat & SFA & MUFA & PUFA & Cholesterol \\
\hline Average daily supply in g or $\mathrm{mg}$ & $270.37 \mathrm{~g}$ & $96.91 \mathrm{~g}$ & $34.79 \mathrm{~g}$ & $37.40 \mathrm{~g}$ & $17.91 \mathrm{~g}$ & $316.02 \mathrm{mg}$ \\
\hline Contribution of milk and dairy products in $\mathrm{g}$ or $\mathrm{mg}$ & $13.60 \mathrm{~g}$ & $10.90 \mathrm{~g}$ & $6.39 \mathrm{~g}$ & $3.28 \mathrm{~g}$ & $0.37 \mathrm{~g}$ & $36.72 \mathrm{mg}$ \\
\hline Contribution of milk and dairy products in \%: & 5.03 & 11.25 & 18.36 & 8.77 & 2.05 & 11.62 \\
\hline Milk & 2.28 & 3.75 & 6.03 & 2.85 & 0.69 & 4.09 \\
\hline whole milk & 1.37 & 2.96 & 4.79 & 2.34 & 0.57 & 3.24 \\
\hline reduced fat milk & 0.82 & 0.72 & 1.13 & 0.46 & 0.11 & 0.75 \\
\hline condensed and powdered milk & 0.09 & 0.07 & 0.11 & 0.06 & 0.01 & 0.10 \\
\hline Cheeses & 0.36 & 5.99 & 9.90 & 4.66 & 1.04 & 5.69 \\
\hline ripened and melted cheeses & 0.02 & 4.59 & 7.51 & 3.61 & 0.81 & 4.25 \\
\hline cottage cheeses & 0.34 & 1.40 & 2.39 & 1.05 & 0.23 & 1.44 \\
\hline Yoghurts, milk drinks and other dairy products & 2.39 & 1.50 & 2.44 & 1.25 & 0.32 & 1.84 \\
\hline yoghurts & 0.63 & 0.39 & 0.62 & 0.33 & 0.10 & 0.51 \\
\hline milk drinks and other dairy products & 1.76 & 1.12 & 1.82 & 0.93 & 0.22 & 1.32 \\
\hline
\end{tabular}

Table 6. Dairy sources of minerals contribution to the average Polish diet (in mg or $\mu \mathrm{g}$ and \%).

\begin{tabular}{|c|c|c|c|c|c|c|c|c|c|}
\hline Specification & Calcium & Phosphorus & Sodium & Potassium & Magnesium & Iron & Zinc & Copper & Iodine \\
\hline Average daily supply in $\mathrm{mg}$ or $\mu \mathrm{g}$ & $644.10 \mathrm{mg}$ & $1160.19 \mathrm{mg}$ & $3,863.84 \mathrm{mg}$ & $2,617.85 \mathrm{mg}$ & $267.33 \mathrm{mg}$ & $10.28 \mathrm{mg}$ & $9.78 \mathrm{mg}$ & $1.11 \mathrm{mg}$ & $154.58 \mu \mathrm{g}$ \\
\hline Contribution of milk and dairy in $\mathrm{mg}$ or $\mu \mathrm{g}$ & $352.26 \mathrm{mg}$ & $285.64 \mathrm{mg}$ & $280.51 \mathrm{mg}$ & $310.74 \mathrm{mg}$ & $29.35 \mathrm{mg}$ & $0.35 \mathrm{mg}$ & $1.36 \mathrm{mg}$ & $0.06 \mathrm{mg}$ & $14.02 \mu \mathrm{g}$ \\
\hline Contribution of milk and dairy products in $\%$ & 54.69 & 24.62 & 7.26 & 11.87 & 10.98 & 3.44 & 13.87 & 5.75 & 9.07 \\
\hline Milk & 21.56 & 9.40 & 1.44 & 6.81 & 5.58 & 1.23 & 4.38 & 2.55 & 3.01 \\
\hline whole milk & 13.70 & 5.88 & 0.89 & 4.11 & 3.57 & 0.76 & 2.58 & 1.98 & 1.94 \\
\hline reduced fat milk & 7.24 & 3.25 & 0.50 & 2.47 & 1.84 & 0.43 & 1.67 & 0.50 & 0.93 \\
\hline condensed and powdered milk & 0.62 & 0.27 & 0.04 & 0.23 & 0.17 & 0.04 & 0.13 & 0.07 & 0.14 \\
\hline Cheeses & 21.42 & 10.09 & 4.96 & 1.21 & 2.51 & 1.33 & 6.67 & 1.67 & 3.80 \\
\hline ripened and melted cheeses & 19.28 & 7.41 & 4.37 & 0.57 & 1.98 & 1.02 & 5.30 & 1.30 & 3.32 \\
\hline cottage cheeses & 2.14 & 2.68 & 0.59 & 0.64 & 0.53 & 0.31 & 1.37 & 0.37 & 0.48 \\
\hline Yoghurts, milk drinks and other dairy products & 11.72 & 5.14 & 0.86 & 3.85 & 2.89 & 0.89 & 2.81 & 1,53 & 2.27 \\
\hline yoghurts & 4.37 & 1.84 & 0.29 & 1.55 & 1.20 & 0.33 & 0.89 & 0.69 & 0.46 \\
\hline milk drinks and other dairy products & 7.35 & 3.30 & 0.57 & 2.30 & 1.69 & 0.56 & 1.92 & 0.85 & 1.80 \\
\hline
\end{tabular}


Table 7. Dairy sources of vitamin contribution to the average Polish diet (in $\mathrm{mg}$ or $\mu \mathrm{g}$ and in\%).

\begin{tabular}{|c|c|c|c|c|c|c|c|c|c|c|}
\hline Specification & Thiamin & Riboflavin & Niacin & Vitamin B6 & Folate & Vitamin B12 & Vitamin C & Vitamin A & Vitamin D & Vitamin $\mathrm{E}$ \\
\hline Average daily supply in $\mathrm{mg}$ or $\mu \mathrm{g}$ & $1.32 \mathrm{mg}$ & $1.59 \mathrm{mg}$ & $16.21 \mathrm{mg}$ & $1.84 \mathrm{mg}$ & $275.02 \mu \mathrm{g}$ & $4.51 \mu \mathrm{g}$ & $91.40 \mathrm{mg}$ & $1,194.55 \mu \mathrm{g}$ & $4.61 \mu \mathrm{g}$ & $13.45 \mathrm{mg}$ \\
\hline Contribution of milk and dairy in $\mathrm{mg}$ or $\mu \mathrm{g}$ & $0.09 \mathrm{mg}$ & $0.45 \mathrm{mg}$ & $0.41 \mathrm{mg}$ & $0.13 \mathrm{mg}$ & $18.07 \mu \mathrm{g}$ & $1.17 \mu \mathrm{g}$ & $2.91 \mathrm{mg}$ & $131.28 \mu \mathrm{g}$ & $0.19 \mu \mathrm{g}$ & $0.35 \mathrm{mg}$ \\
\hline Contribution of milk and dairy products in \%: & 6.67 & 28.15 & 2.53 & 7.12 & 6.57 & 26.14 & 3.18 & 10.99 & 4.22 & 2.61 \\
\hline Milk & 4.02 & 13.45 & 1.53 & 3.85 & 2.35 & 10.28 & 2.27 & 4.38 & 2.11 & 1.29 \\
\hline whole milk & 2.26 & 8.29 & 0.69 & 2.02 & 1.06 & 6.38 & 1.30 & 3.05 & 0.95 & 0.75 \\
\hline reduced fat milk & 1.67 & 4.82 & 0.81 & 1.74 & 1.23 & 3.69 & 0.91 & 1.27 & 1.15 & 0.53 \\
\hline condensed and powdered milk & 0.10 & 0.34 & 0.03 & 0.09 & 0.06 & 0.21 & 0.07 & 0.05 & 0.02 & 0.01 \\
\hline Cheeses & 0.73 & 7.60 & 0.41 & 1.30 & 2.65 & 9.50 & 0.03 & 5.18 & 1.76 & 0.96 \\
\hline ripened and melted cheeses & 0.38 & 3.79 & 0.20 & 0.58 & 1.29 & 6.66 & 0.00 & 4.13 & 1.23 & 0.68 \\
\hline cottage cheeses & 0.35 & 3.81 & 0.21 & 0.72 & 1.36 & 2.84 & 0.03 & 1.05 & 0.53 & 0.28 \\
\hline Yoghurts, milk drinks and other dairy products & 1.92 & 7.09 & 0.58 & 1.97 & 1.58 & 6.35 & 0.89 & 1.43 & 0.35 & 0.37 \\
\hline yoghurts & 0.73 & 2.51 & 0.23 & 0.76 & 0.58 & 2.13 & 0.70 & 0.48 & 0.11 & 0.18 \\
\hline milk drinks and other dairy products & 1.18 & 4.59 & 0.36 & 1.22 & 1.00 & 4.22 & 0.19 & 0.95 & 0.24 & 0.19 \\
\hline
\end{tabular}




\subsection{Summary}

To analyze the impact of socio-demographic and economic features of the households on the level and structure of energy and nutrient supply from dairy category in the average Polish diet, main dairy product groups (milk, cheeses as well as yoghurts, milk drinks, and other dairy products) were selected. The largest impact was observed in the case of the following factors: size of the village, socio-economic affiliation of the household, education, and land use (Table 8). Clusters differ in the consumption of milk, cheeses, as well as yoghurts, milk drinks and other dairy products (Table 9), which differentiates the supply of energy and nutrients from these products to the average diet (Figures 1-3).

Table 8. Cluster analysis: impact of socio-demographic and economic factors on energy and nutrients contribution from dairy products in the average Polish diet.

\begin{tabular}{cc}
\hline Factors & Cramer Correlations \\
\hline size of the village & 0.150 \\
socio-economic affiliation & 0.149 \\
land use & 0.146 \\
education & 0.146 \\
family life phase & 0.140 \\
degree of urbanization & 0.139 \\
age & 0.129 \\
region & 0.116 \\
income (quintile group) & 0.113 \\
assessment of financial situation & 0.099 \\
assessment of nutrition & 0.077 \\
number of people in household & 0.075 \\
study month & 0.053 \\
sex & 0.010 \\
\hline
\end{tabular}

Table 9. Cluster analysis: consumption of main dairy product groups.

\begin{tabular}{lcccc}
\hline \multicolumn{1}{c}{ Specification } & Sample Population & Cluster 1 & Cluster 2 & Cluster 3 \\
\hline $\begin{array}{l}\text { Number of households } \\
\text { Number of persons in households }\end{array}$ & 36,886 & 7,425 & 15,804 & 13,657 \\
\hline Consumption Per 1 Person Per Month & 99,230 & 20,887 & 41,321 & 37,022 \\
\hline milk (in liters) & & & & \\
$\begin{array}{l}\text { cheeses (in kg) } \\
\text { yoghurts, milk drinks and other dairy }\end{array}$ & 3.51 & 2.73 & 2.08 & 5.62 \\
products (in kg) & 1.92 & 1.04 & 1.15 & 0.71 \\
\hline
\end{tabular}




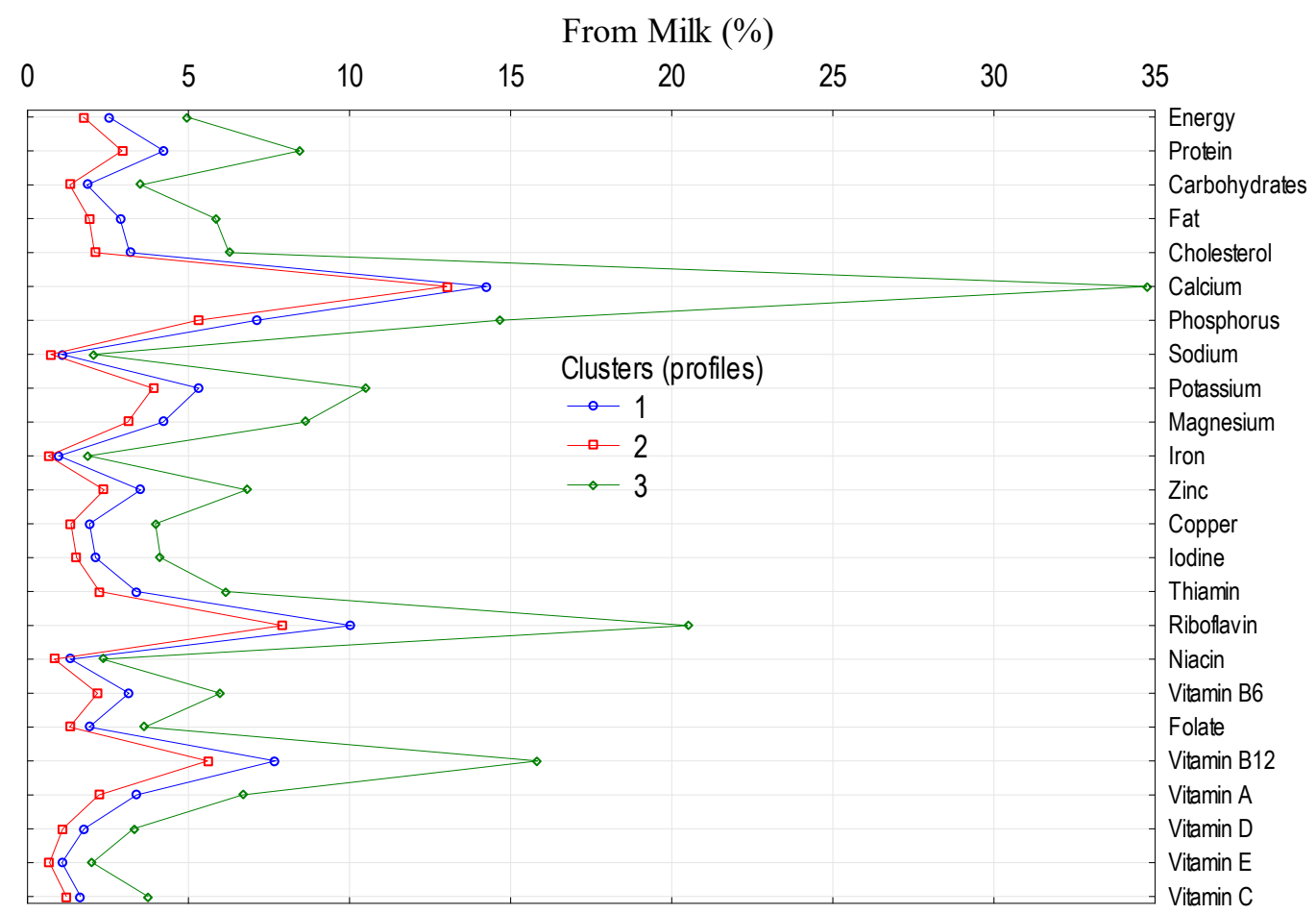

Figure 1. Cluster analysis: supply of energy and nutrients to the average Polish diet.

From Cheeses (\%)

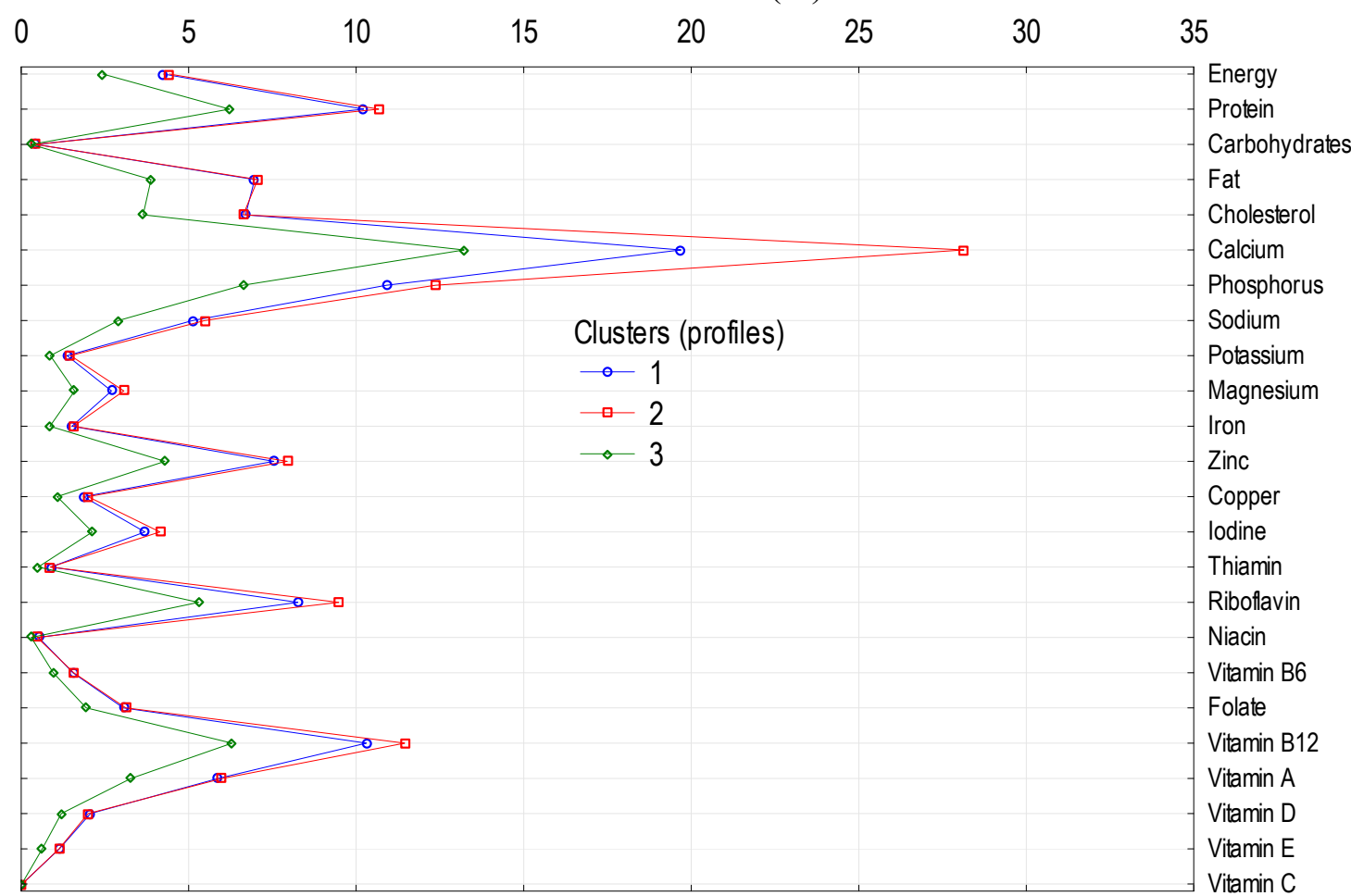

Figure 2. Cluster analysis: supply of energy and nutrients from cheeses to the average Polish diet. 


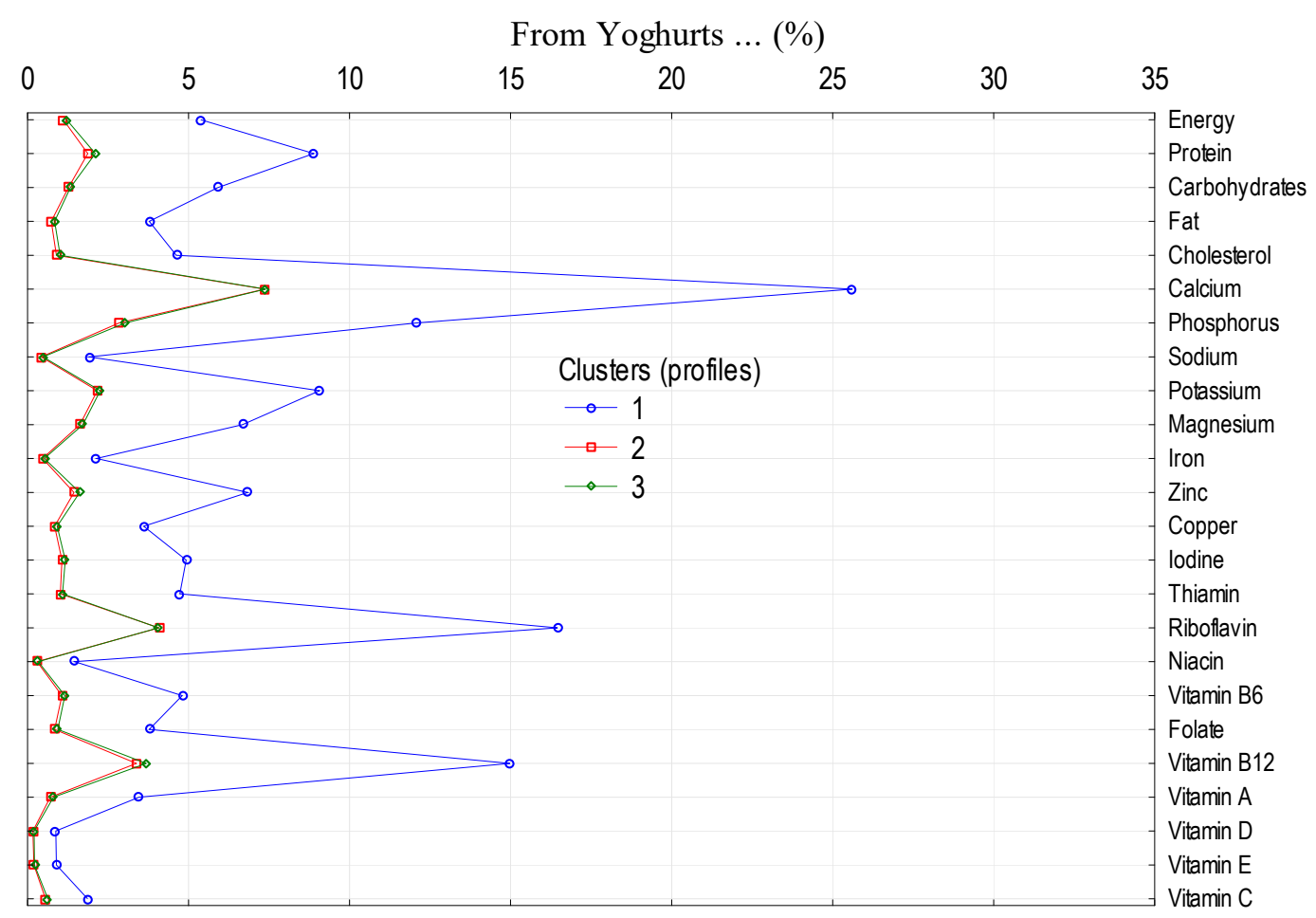

Figure 3. Cluster analysis: supply of energy and nutrients from yoghurts, milk drinks and other dairy products to the average Polish diet.

\section{Discussion}

Milk and dairy products are an important food category in the structure of the Polish diet. The aim of this study was to determine the importance of this product category in the supply of energy, macronutrients (including amino acids), minerals and vitamins. Particular attention was paid to product groups (i.e., milk, cheeses as well as yoghurts, and milk drinks) and sub-groups (e.g., whole milk, reduced fat milk, condensed and powdered milk, ripened and melted cheeses, cottage cheeses, yoghurts as well as milk drinks and other dairy products). The obtained results were compared with the results described in the scientific literature referring to other populations, including the American [53,64], Spanish [65-68], Dutch [69,70], New Zealand [71] and Australian [72-74] population.

In the structure of energy supply to the average Polish diet, the share of milk and its products was at the level of $9.1 \%$, providing $205 \mathrm{kcal}$ from the total energy value of the Polish diet. The largest share of dairy products in supplying energy was cheese (3.7\%) and milk (3.2\%). In the average American diet, milk and dairy products provided $10.6 \%$ of the total energy supply. The share of cheeses amounted to $6.8 \%$, milk-3.8\%, and dairy desserts-2.2\% [53]. Detailed data from 2007-2010 indicate the supply of energy from dairy products in the following order: cheese (ripened cheese: $2.6 \%$, macaroni and cheese: $0.8 \%$, cottage/ricotta cheese: $0.4 \%$ ), milk (reduced fat: $2.2 \%$, nonfat: $1.3 \%$, whole fat: $1.0 \%$ and low fat $1.0 \%)$, ice cream, frozen dairy desserts (1.9\%), and yoghurts (0.5\%) [75]. In the population of Americans over 51 years, the share of milk and dairy products in energy supply was calculated at $6.5 \%$, including the two main product sub-groups, i.e., milk $2.8 \%$ and cheese $2.2 \%$ [64]. In the study of the population from New Zealand, similar results were obtained in comparison to the average Polish diet. The total share of dairy products in the energy supply amounted to $9.4 \%$, of which milk provided $5 \%$ of the total energy supply, cheese- $-2.5 \%$ and dairy products- $-1.9 \%$ [71].

According to our research, milk and dairy products provided $18.1 \%$ of total protein supply in the average Polish diet, of which almost half are made of rennet, melted and cottage cheese $(9.0 \%)$. In the average American diet, the share of cheeses in total protein supply was $8.5 \%$, whole milk-6.9\% [53]. Detailed research from 2007-2010 regarding the importance of dairy products in the American diet indicated a varied supply of protein from dairy products, including cheese (ripened cheese: $4.3 \%$, 
macaroni and cheese: $1.0 \%$, cottage/ricotta cheese: $0.1 \%$ ), milk (reduced fat: $1.3 \%$, nonfat: $0.6 \%$, whole fat: $0.7 \%$ and low fat $0.5 \%)$, ice cream and frozen dairy desserts $(1.0 \%)$ and yoghurts $(0.7 \%)$ [75]. In the New Zealand population, the share of milk and its products in the supply of protein was $13.9 \%$, including milk $8.8 \%$, cheese $3.1 \%$, and dairy products $2.0 \%$ [71]. The significance of protein supply to the average diet is a very important issue, therefore this aspect combined with energy supply is included in the nutrient density indicators used to analyze the quality of diets [76], i.e., NQI (Nutritional Quality Index of foods) [76-78], RRR score (ratio of recommended to restricted food score) [76], calories-for-nutrient (CFN) score [76], and naturally nutrient rich (NNR) score [76,77].

Considering the supply of protein in the diet, special attention should be paid to the supply of amino acids from the dairy category in general and for individual dairy products. In the average Polish diet, the share of milk and dairy products in the supply of branched-chain amino acids (leucine, isoleucine and valine, BCAAs) ranged from 19 to $21 \%$. This is especially important because of the role of BCAAs in muscle protein synthesis [79-81].

In the average Polish diet, the share of milk and milk products in the supply of total fat was $11.3 \%$, with SFA reaching almost $18.5 \%$, and for MUFA- $8.8 \%$. The structure of total fat supply in general was dominated by cheeses, above all ripened and melted, while the share of milk amounted to 3.8\%. When comparing the role of the dairy category, it should be emphasized that in the average American diet, the share of cheeses was $8.8 \%$ in the supply of total fats. Milk delivered 3.7\% of total fat supply, and milk desserts-2.7\% [53]. In the population of Americans over the age of 51, milk and dairy products provided $7.5 \%$ of the total supply of fat, and 14.1\% of SFA [64]. In contrast, in the New Zealand diet, the share of milk and dairy products in the total supply of fats amounted to $12.4 \%$ with particular reference to milk-5\%, cheeses-4.1\% and dairy products-3.3\%. SFA supply from milk and dairy products amounted to $18.6 \%$, including $7.6 \%$ of milk, $6.3 \%$ of cheese and $4.7 \%$ of dairy products [71].

The supply of cholesterol from milk and dairy products in the average Polish diet was at the level of $11.6 \%$, of which cheese provided $5.7 \%$ of the total daily intake of cholesterol, and milk-4.1\%. Studies conducted in the American population indicate the supply of cholesterol from the dairy products category at the similar level (11.2\%) [82]. A slightly higher level of supply of cholesterol from milk and dairy products was recorded in the New Zealand population (14.3\%), including milk (8\%), dairy products $(3.5 \%)$, and cheese $(2.8 \%)$ [71].

Of the analyzed minerals, special attention should be paid to calcium. In the average Polish diet, milk and dairy products provided more than half of the total supply of calcium. The role of milk and cheese is comparable, in both cases there was a share in supply at the level of about $21.5 \%$. However, the share of yoghurts, milk drinks and other dairy products was almost $12 \%$. Similar results were obtained for the American population, the share of milk in the supply of calcium was $22.5 \%$, cheese-21.6\%, milk desserts 3.5\%, and milk drinks-2.0\% [53]. Subsequent studies conducted in the United States on a sample of adults over 51 years indicate a combined share of milk and dairy products in the supply of calcium at 32.8\% [64]. In the average Spanish diet, the share of milk and dairy products in the supply of calcium was at a similar level, which in Poland amounted to 53.1\% [67]. A slightly higher index was obtained for the Dutch population including persons aged 7-69, the share of dairy products in the calcium supply amounted to 58\% [69,70]. In the New Zealand population, the share of milk and its products in the supply of calcium amounted to $40.3 \%$, of which the share of milk was at the level of $26.8 \%$, cheese $-7.7 \%$, and dairy products $-5.8 \%$ [71]. The analysis of calcium supply from milk and dairy products is particularly important in the context of the importance of this nutrient for good bone health $[8,15,16]$, in reducing cholesterol absorption, controlling body weight and blood pressure [1], and preventing periodontal disease [17-21].

Changes in the consumption of milk and dairy products affect the supply of calcium, which, due to the importance of calcium in metabolic processes [83], may have negative health implications. Therefore, calcium (like protein) is taken into account in the indicators of nutritional density, i.e., NQI (Nutritional Quality Index of foods), RRR score (ratio of recommended to restricted food score), calories-for-nutrient (CFN) score, and naturally nutrient rich (NNR) score [76,77]. 
According to our research, milk and dairy products provided almost $\frac{1}{4}$ of phosphorus supply, including $10.1 \%$ of cheese, and $9.4 \%$ of milk. Similar results were achieved for the average American diet, milk provided $12.3 \%$ of phosphorus, cheese-11.3\%, while milk desserts-2.0\% [53]. In the average Dutch diet (data covering people aged 7-69), the share of dairy products in phosphorus supply amounted to $32 \%[69,70]$.

The share of milk and dairy products at the level of $10 \%-15 \%$ in the supply of minerals to the average Polish diet was noted for zinc (13.9\%), potassium (11.9\%) and magnesium (11.0\%). According to Spanish study, milk and its products provided a higher percentage of zinc to the average diet $(16 \%)$ [67]. Other studies indicate the supply of zinc from milk and its products at $12-15 \%$ in the Australian diet [72,73], and 13\% in the average American diet [84]. In the average New Zealand diet, the share of milk and its products in the supply of zinc was $12.4 \%$, of which milk was responsible for $7.4 \%$ of zinc, cheeses $-3.3 \%$ and dairy products $-1.7 \%$ [71].

The scientific literature indicates the importance of adequate supply of zinc in growth and development, immunological processes, reproductive immunity, neurological function and reproduction $[74,85,86]$. The importance of milk and dairy products in the zinc supply in the population is also underlined $[67,74,85-89]$. For example, in studies on the sources of zinc in the diet of Australian children from 1995 and 2007, there was a decrease in the share of dairy products in the supply of zinc from 18-24\% in 1995 to $15-20 \%$ [74]. This is the reason for including zinc in the composition of indicators assessing the nutritional quality of the diet i.e., calories-for-nutrient (CFN), and naturally nutrient rich (NNR) score [76-78,90].

According to our research, the share of milk and dairy products in the supply of potassium is almost $12 \%$, with a significant share of milk. In the American diet, the share of milk in potassium supply is $9.6 \%$ [53]. These considerations should be combined with the importance of potassium in regulating blood pressure [91,92], membrane transport, energy metabolism, and cell functioning [93].

According to our research, milk and dairy products provided over $25 \%$ of riboflavin and vitamin B12, and $11 \%$ of vitamin A to the average Polish diet. In the supply of riboflavin, the share of milk was $13.6 \%$, while cheese and milk drinks, including yoghurts, provided riboflavin in an amount of $7-8 \%$ of the daily supply of this vitamin. In the average New Zealand diet, the share of dairy category in the riboflavin supply exceeded $30 \%$ with milk contribution at the level of $22.9 \%$, dairy products-4.8\% and cheese-2.9\% [71]. Among the analyzed dairy products in the structure of vitamin B12 supply, the first place was taken by milk ( $10.3 \%$ of the total daily supply of this vitamin), followed by cheese $(9.5 \%)$ and yoghurts, milk drinks and other dairy products (6.4\%). A similar supply of dairy products in the supply of vitamin B12 was recorded in the New Zealand population (29.5\%). The share of milk in the supply of this vitamin was $20.6 \%$, cheese $4.7 \%$, and dairy products $4.2 \%$ [71]. In the structure of vitamin A supply from the group of dairy products, the largest share concerned cheeses, in particular ripened and melted cheeses, and milk, including whole milk. In the New Zealand population, the share of milk and its products in the supply of vitamin A was at a higher level of $15.3 \%$. From this amount, the share of milk was $6.2 \%$, cheeses $-4.9 \%$, and dairy products- $4.7 \%$ [71].

In summary, we should point to the significance of milk and dairy products in the supply of nutrients as nutrient-dense foods. This is important due to the concentration of protein and nutrients crucial for growth and health, i.e., calcium, magnesium, potassium, zinc, and phosphorus [7-13]. In spite of the limitations $[49,51]$ we mentioned in previous studies, our research is an important source of information for analyzing sources of nutrients in the average Polish diet, its structure and quality.

\section{Conclusions}

The results of our analysis showed that milk and dairy products are especially valuable food in the average Polish diet, thus confirming that they belong to foods with particularly high nutritional density. In addition, all milk and dairy products' ingredients are well absorbed. The exception is lactose, poorly tolerated in some people, but they can choose fermented dairy products, taking advantage of the presence of probiotic bacteria, a health-promoting bioactive ingredient. 
From the three main groups of dairy products analysed, cheese and milk provide the most energy and nutrients. These main groups are significant sources of calcium as each provides about $22 \%$ of this nutrient (the total contribution of calcium from dairy products is 55\%). The role of milk and dairy products in providing calcium cannot be overestimated, but its average intake in Poland is low and is around $60 \%$ of the recommended intake. The share of milk and cheese groups in the supply of phosphorus, potassium and magnesium is twice lower. In the case of vitamins, the role of milk and dairy products in the supply of riboflavin and vitamin B12 should be emphasized. Milk provides almost twice as much riboflavin as cheese.

The share of the third group of analyzed dairy products, i.e., yoghurts, milk drinks and other dairy products in supplying nutrients to the average Polish diet was in each case lower than milk and cheese (as the consumption is lower), with the exception of carbohydrates. The contribution of this group of dairy products was $2.4 \%$. Paradoxically, fermented milk drinks are recommended for people intolerant to lactose, but manufacturers practice adding (too much) sugar to flavored and fruit yogurt and milk drinks, especially for children.

The results of our analysis may be helpful in developing dietary guidelines on the amount and structure of milk and dairy products' consumption in order to achieve better health status of the population.

Author Contributions: H.G.-W. contributed to article design, food grouping, data analysis, and discussion, W.L. conducted calculations from the primary database of the 2016 HBS using the R environment; K.R. was involved in the introduction and discussion, M.C. contributed to analysis. All authors participated in conclusions, read and approved the final manuscript.

Funding: The publication was financed by Polish Ministry of Science and Higher Education within funds of Faculty of Human Nutrition and Consumer Sciences, Warsaw University of Life Sciences (WULS), for scientific research.

Acknowledgments: The authors are grateful to the Central Statistical Office in Warsaw; the analysis was conducted based on the primary data of the 2016 Household Budget Survey.

Conflicts of Interest: The authors declare no conflict of interest.

\section{References}

1. Park, Y.W. Introduction: Overview of bioactive components in milk and dairy products. In Bioactive Components in Milk and Dairy Products; Park, Y.W., Ed.; Publishers, Wiley- Blackwell: Ames, Iowa; Oxford, UK, 2009; pp. 3-14. ISBN 978-3-86944-021-7.

2. Haug, A.; Høstmark, A.T.; Harstad, O.M. Bovine milk in human nutrition - A review. Lipids Health Dis. 2007, 6, 1-16. [CrossRef] [PubMed]

3. Visioli, F.; Strata, A. Milk, dairy products, and their functional effects in humans: A narrative review of recent evidence. Adv. Nutr. 2014, 5, 131-143. [CrossRef] [PubMed]

4. Mcgrane, M.M.; Essery, E.; Obbagy, J.; Lyon, J.; Macneil, P.; Spahn, J.; van Horn, L. Dairy consumption, blood pressure, and risk of hypertension: An evidence-based review of recent literature. Curr. Cardiovasc. Risk Rep. 2011, 5, 287-298. [CrossRef] [PubMed]

5. FAO Gateway to Dairy Production and Products FAO 2018 Food and Agriculture Organization of the United Nations. Available online: http://www.fao.org/dairy-production-products/production/en/ (accessed on 6 July 2019).

6. Merdji, M.; Gacic, M.K.; Ciheam-Maim, S.T. The Dairy Products Market. Available online: http://www. enpicbcmed.eu/sites/default/files (accessed on 13 June 2019).

7. Muehlhoff, E.; Bennett, A.; Mcmahon, D. Milk and Dairy Products in Human Nutrition; Food and Agriculture Organization of the United Nations: Rome, Italy, 2013; ISBN 9789251078631.

8. Rizzoli, R. Dairy products, yogurts, and bone health. Am. J. Clin. Nutr. 2014, 99, 1256S-1262S. [CrossRef] [PubMed]

9. Black, R.E.; Williams, S.M.; Jones, I.E.; Goulding, A. Children who avoid drinking cow milk have low dietary calcium intakes and poor bone health. Am. J. Clin. Nutr. 2002, 76, 675-680. [CrossRef] [PubMed] 
10. Bailey, R.L.; Dodd, K.W.; Goldman, J.A.; Gahche, J.J.; Dwyer, J.T.; Moshfegh, A.J.; Sempos, C.T.; Picciano, M.F. Estimation of total usual calcium and vitamin D intakes in the United States. J. Nutr. 2010, 24, 817-822. [CrossRef] [PubMed]

11. Bechthold, A.; Boeing, H.; Schwedhelm, C.; Hoffmann, G.; Knüppel, S.; Iqbal, K.; De Henauw, S.; Michels, N.; Devleesschauwer, B.; Schlesinger, S.; et al. Food groups and risk of coronary heart disease, stroke and heart failure: A systematic review and dose-response meta-analysis of prospective studies. Crit. Rev. Food Sci. Nutr. 2019, 59, 1071-1090. [CrossRef]

12. Kardinaal, A.F.M.; Ando, S.; Charles, P.; Charzewska, J.; Rotily, M.; Väänänen, K.; Van Erp-Baart, A.M.J.; Heikkinen, J.; Thomsen, J.; Maggiolini, M.; et al. Dietary calcium and bone density in adolescent girls and young women in Europe. J. Bone Miner. Res. 1999, 14, 583-592. [CrossRef] [PubMed]

13. Pfeuffer, M.; Watzl, B. Nutrition and health aspects of milk and dairy products and their ingredients. Ernahr. Umschau Sci. Res. 2017, 65, 22-33. [CrossRef]

14. Franzoi, M.; Niero, G.; Penasa, M.; Cassandro, M.; De Marchi, M. Technical note: Development and validation of a new method for the quantification of soluble and micellar calcium, magnesium, and potassium in milk. J. Dairy Sci. 2017, 101, 1883-1888. [CrossRef]

15. Bonjour, J.-P. Dietary protein: an essential nutrient for bone health. J. Am. Coll. Nutr. 2005, 24, 526S-536S. [CrossRef] [PubMed]

16. Zhu, K.; Prince, R.L. Calcium and bone. Clin. Biochem. 2012, 45, 936-942. [CrossRef]

17. Adegboye, A.R.A.; Christensen, L.B.; Holm-Pedersen, P.; Avlund, K.; Boucher, B.J.; Heitmann, B.L. Intake of dairy products in relation to periodontitis in older danish adults. Nutrients 2012, 4, 1219-1229. [CrossRef]

18. Lee, K.; Kim, J. Dairy food consumption is inversely associated with the prevalence of periodontal disease in Korean adults. Nutrients 2019, 11, 1035. [CrossRef] [PubMed]

19. Al-Zahrani, M.S. Increased intake of dairy products is related to lower periodontitis prevalence. J. Periodontol. 2006, 77, 289-294. [CrossRef]

20. Schifferle, R.E. Nutrition and periodontal disease. Dent. Clin. North Am. 2005, 49, 595-610. [CrossRef] [PubMed]

21. Shimazaki, Y.; Shirota, T.; Uchida, K.; Yonemoto, K.; Kiyohara, Y.; Iida, M.; Saito, T.; Yamashita, Y. Intake of dairy products and periodontal disease: The hisayama study. J. Periodontol. 2008, 79, 131-137. [CrossRef] [PubMed]

22. De Oliveira Otto, M.C.; Lemaitre, R.N.; Song, X.; King, I.B.; Siscovick, D.S.; Mozaffarian, D. Serial measures of circulating biomarkers of dairy fat and total and cause-specific mortality in older adults: The cardiovascular health study. Am. J. Clin. Nutr. 2018, 108, 476-484. [CrossRef]

23. Nilsen, R.; Høstmark, A.T.; Haug, A.; Skeie, S. Effect of a high intake of cheese on cholesterol and metabolic syndrome: Results of a randomized trial. Food Nutr. Res. 2015, 59, 27651. [CrossRef] [PubMed]

24. Engel, S.; Elhauge, M.; Tholstrup, T. Effect of whole milk compared with skimmed milk on fasting blood lipids in healthy adults: A 3-week randomized crossover study. Eur. J. Clin. Nutr. 2018, 72, 249-254. [CrossRef] [PubMed]

25. Guo, J.; Astrup, A.; Lovegrove, J.A.; Gijsbers, L.; Givens, D.I.; Soedamah-Muthu, S.S. Milk and dairy consumption and risk of cardiovascular diseases and all-cause mortality: Dose-response meta-analysis of prospective cohort studies. Eur. J. Epidemiol. 2017, 32, 269-287. [CrossRef] [PubMed]

26. Pimpin, L.; Wu, J.H.Y.; Haskelberg, H.; Del Gobbo, L.; Mozaffarian, D. Is butter back? A systematic review and meta-analysis of butter consumption and risk of cardiovascular disease, diabetes, and total mortality. PLoS ONE 2016, 11, e0158118. [CrossRef] [PubMed]

27. Yu, E.; Hu, F.B. Dairy products, dairy fatty acids, and the prevention of cardiometabolic disease: A review of recent evidence. Curr. Atheroscler. Rep. 2018, 20, 24. [CrossRef] [PubMed]

28. Sun, Q.; Ma, J.; Campos, H.; Hu, F.B. Plasma and erythrocyte biomarkers of dairy fat intake and risk of ischemic heart disease. Am. J. Clin. Nutr. 2007, 86, 929-937. [CrossRef] [PubMed]

29. Pranger, I.G.; Muskiet, F.A.J.; Kema, I.P.; Singh-Povel, C.; Bakker, S.J.L. Potential biomarkers for fat from dairy and fish and their association with cardiovascular risk factors: Cross-sectional data from the lifelines biobank and cohort study. Nutrients 2019, 11, 1099. [CrossRef] [PubMed]

30. Tong, X.; Chen, G.C.; Zhang, Z.; Wei, Y.L.; Xu, J.Y.; Qin, L.Q. Cheese consumption and risk of all-cause mortality: A meta-analysis of prospective studies. Nutrients 2017, 9, 63. [CrossRef] [PubMed] 
31. Farvid, M.S.; Malekshah, A.F.; Pourshams, A.; Poustchi, H.; Sepanlou, S.G.; Sharafkhah, M.; Khoshnia, M.; Farvid, M.; Abnet, C.C.; Kamangar, F.; et al. Dairy food intake and all-cause, cardiovascular disease, and cancer mortality: The Golestan cohort study. Am. J. Epidemiol. 2017, 185, 697-711. [CrossRef] [PubMed]

32. Chen, M.; Sun, Q.; Giovannucci, E.; Mozaffarian, D.; Manson, J.E.; Willett, W.C.; Hu, F.B. Dairy consumption and risk of type 2 diabetes: 3 cohorts of US adults and an updated meta-analysis. BMC Med. 2014, 12, 215. [CrossRef] [PubMed]

33. Gijsbers, L.; Ding, E.L.; Malik, V.S.; de Goede, J.; Geleijnse, J.M.; Soedamah-Muthu, S.S. Consumption of dairy foods and diabetes incidence: a dose-response meta-analysis of observational studies. Am. J. Clin. Nutr. 2016, 103, 1111-1124. [CrossRef] [PubMed]

34. Aune, D.; Norat, T.; Romundstad, P.; Vatten, L.J. Dairy products and the risk of type 2 diabetes: a systematic review and dose-response meta-analysis of cohort studies. Am. J. Clin. Nutr. 2013, 98, 1066-1083. [CrossRef]

35. Hruby, A.; Ma, J.; Rogers, G.; Meigs, J.B.; Jacques, P.F. Associations of dairy intake with incident prediabetes or diabetes in middle-aged adults vary by both dairy type and glycemic status. J. Nutr. 2017, 147, 1764-1775. [CrossRef] [PubMed]

36. Lu, W.; Chen, H.; Niu, Y.; Wu, H.; Xia, D.; Wu, Y. Dairy products intake and cancer mortality risk: a meta-analysis of 11 population-based cohort studies. Nutr. J. 2016, 15, 91. [CrossRef] [PubMed]

37. Wiseman, M.; Thompson, R.; Allen, K. Diet, Nutrition, Physical Activity and Cancer: a Global Perspective. A summary of the Third Expert Report; World Cancer Research Fund and American Institute for Cancer Research, Diet, Nutrition, Physical Activity and Cancer, WCRF International Ed.: London, UK, 2008; ISBN 9781912259465.

38. Dehghan, M.; Mente, A.; Zhang, X.; Swaminathan, S.; Li, W.; Mohan, V.; Iqbal, R.; Kumar, R.; Wentzel-Viljoen, E.; Rosengren, A.; et al. Associations of fats and carbohydrate intake with cardiovascular disease and mortality in 18 countries from five continents (PURE): A prospective cohort study. Lancet 2017, 391, 1679-1680. [CrossRef]

39. Phelan, M.; Kerins, D. The potential role of milk-derived peptides in cardiovascular disease. Food Funct. 2011, 2, 153-167. [CrossRef] [PubMed]

40. De Goede, J.; Soedamah-Muthu, S.S.; Pan, A.; Gijsbers, L.; Geleijnse, J.M. Dairy consumption and risk of stroke: A systematic review and updated dose-response meta-analysis of prospective cohort studies. J. Am. Heart Assoc. 2016, 5, e002787. [CrossRef] [PubMed]

41. Bhat, Z.F.; Bhat, H. Milk and dairy products as functional foods: A review. Int. J. Dairy Sci. 2011, 6, 1-12. [CrossRef]

42. Dunshea, F.R.; Ostrowska, E.; Ferrari, J.M.; Gill, H.S. Dairy proteins and the regulation of satiety and obesity. Aust. J. Exp. Agric. 2007, 47, 1052-1058. [CrossRef]

43. Alzamora, S.M.; Salvatori, D.; Tapia, M.S.; López-Malo, A.; Welti-Chanes, J.; Fito, P. Novel functional foods from vegetable matrices impregnated with biologically active compounds. J. Food Eng. 2005, 67, 205-214. [CrossRef]

44. Buttriss, J. Nutritional properties of fermented milk products. Int. J. Dairy Technol. 1997, 50, 21-27. [CrossRef]

45. Household Budget Survey in 2016; Central Statistical Office: Warsaw, Poland, 2017.

46. Barlik, M.; Siwiak, K. (Eds.) Methodology of Household Survey (in Polish); Central Statistical Office, Zakład Wydawnictw Statystycznych: Warsaw, Poland, 2011.

47. Laskowski, W.; Górska-Warsewicz, H. Nutrient Density of the Average Polish Diet. Economic Analysis (in Polish), 1st ed.; Laskowski Publisher: Warsaw, Poland, 2014; ISBN 978-83-941257-1-4.

48. Rejman, K.; Kowrygo, B.; Laskowski, W. Evaluation of the structure of food consumption in poland in the context of demands of sustainable consumption (in Polish). J. Agribus. Rural Dev. 2015, 37, 503-512. [CrossRef]

49. Górska-Warsewicz, H.; Laskowski, W.; Kulykovets, O.; Kudlińska-Chylak, A.; Czeczotko, M.; Rejman, K. Food products as sources of protein and amino acids-The case of Poland. Nutrients 2018, 10, 1977. [CrossRef] [PubMed]

50. Laskowski, W.; Górska-Warsewicz, H.; Kulykovets, O. Meat, meat products and seafood as sources of energy and nutrients in the average Polish diet. Nutrients 2018, 10, 1412. [CrossRef] [PubMed]

51. Laskowski, W.; Górska-Warsewicz, H.; Rejman, K. How important are cereals and cereal products in the average Polish diet? Nutrients 2019, 11, 679. [CrossRef] [PubMed] 
52. What We Eat in America. Available online: https://www.ars.usda.gov/arsuserfiles/80400530/pdf/1314/Food_ categories_2013-2014.pdf (accessed on 13 August 2018).

53. O'Neil, C.E.; Keast, D.R.; Fulgoni, V.L.; Nicklas, T.A. Food sources of energy and nutrients among adults in the US: NHANES 2003-2006. Nutrients 2012, 4, 2097-2120. [CrossRef] [PubMed]

54. Scientific Report of the 2015 Dietary Guidelines Advisory Committee Appendix E-2.7: Major Categories and Subcategories Used in DGAC Analyses of WWEIA Food Categories Part E. Section 2: Supplementary Documentation to the 2015 DGAC Report Scie. Available online: https://health.gov/dietaryguidelines/DGACMajor-categories-and-subcategories-from-WWEIA-FoodCategories.pdf (accessed on 13 August 2018).

55. Rhodes, D.G.; Adler, M.E.; Clemens, J.C.; Moshfegh, A.J. What we eat in America food categories and changes between survey cycles. J. Food Compos. Anal. 2017, 64, 107-111. [CrossRef]

56. Kunachowicz, H.; Przygoda, B.; Nadolna, I.; Iwanow, K. Nutritive Tables for Foods and Meals (in Polish), 4th ed.; PZWL Wydawnictwo Lekarskie: Warsaw, Poland, 2017; ISBN 978832005311.

57. Fox, J.; Leanage, A. R and the journal of Statistical Software. J. Stat. Softw. 2016, 73, 1-13. [CrossRef]

58. R Development Core Team R Language Definition. Available online: https://cran.r-project.org/doc/manuals/ r-release/R-lang.pdf (accessed on 8 August 2018).

59. Lang, M. Efficient R programming. J. Stat. Softw. 2017, 80. [CrossRef]

60. Dubes, R.; Jain, A.K. Clustering methodologies in exploratory data analysis. Adv. Comput. 1980, 19, 113-228.

61. Parsons, L.; Haque, E.; Liu, H. Subspace clustering for high dimensional data. ACM SIGKDD Explor. Newsl. 2004, 6, 90-105. [CrossRef]

62. Wilks, D.S. Cluster analysis. Int. Geophys. 2011, 100, 603-616.

63. R.Rojas 15 Kohonen Networks 15.1. In Neural Networks; Springer-Verlag: Berlin, Germany, 1996; pp. $391-412$. ISBN 9783540605058.

64. Papanikolaou, Y.; Fulgoni, V. Grains Contribute shortfall nutrients and nutrient density to older US adults: data from the national health and nutrition examination survey, 2011-2014. Nutrients 2018, 10, 534. [CrossRef] [PubMed]

65. Mielgo-Ayuso, J.; Aparicio-Ugarriza, R.; Olza, J.; Aranceta-Bartrina, J.; Gil, Á.; Ortega, R.; Serra-Majem, L.; Varela-Moreiras, G.; González-Gross, M. Dietary Intake and food sources of niacin, riboflavin, thiamin and vitamin b6 in a representative sample of the Spanish population. The anthropometry, intake, and energy balance in Spain (ANIBES) study t. Nutrients 2018, 10, 846. [CrossRef] [PubMed]

66. Olza, J.; Aranceta-Bartrina, J.; González-Gross, M.; Ortega, R.M.; Serra-Majem, L.; Varela-Moreiras, G.; Gil, Á. Reported dietary intake and food sources of zinc, selenium, and vitamins a, e and $\mathrm{c}$ in the spanish population: Findings from the anibes study. Nutrients 2017, 9, 697. [CrossRef] [PubMed]

67. Olza, J.; Aranceta-Bartrina, J.; González-Gross, M.; Ortega, R.M.; Serra-Majem, L.; Varela-Moreiras, G.; Gil, Á. Reported dietary intake, disparity between the reported consumption and the level needed for adequacy and food sources of calcium, phosphorus, magnesium and vitamin D in the Spanish population: Findings from the ANIBES study. Nutrients 2017, 9, 168. [CrossRef] [PubMed]

68. Rubio, C.; Gutiérrez, Á.J.; Revert, C.; Reguera, J.I.; Burgos, A.; Hardisson, A. Daily dietary intake of iron, copper, zinc and manganese in a Spanish population. Int. J. Food Sci. Nutr. 2009, 60, 590-600. [CrossRef] [PubMed]

69. Tijhuis, M.J.; Ezendam, J.; Westenbrink, S.; van Rossum, C.; Temme, L. Replacement of Meat and Dairy by More Sustainable Protein Sources in The Netherlands Quality of the Diet; National Institute for Public Health and the Environment, Ministry of Health, Welfare and Sport: Bilthoven, Denmark, 2011.

70. Van Rossum, C.T.M.; Fransen, H.; Verkaik-Kloosterman, J.; Buurma-Rethans, E.; Ocke, M. National Food Consumption Survey: Dutch National Food Consumption Survey 2007-2010; National Institute for Public Health and the Environment, Ministry of Health, Welfare and Sport: Bilthoven, Denmark, 2011.

71. A focus on nutrition: Key findings of the 2008/09 New Zealand Adult Nutrition Survey; University of Otago: Dunedin, New Zealand; Ministry of Health: Wellington, New Zealand, 2011; ISBN 9780478373486.

72. Mclennan, W.; Podger, A. National Nutrition Survey Nutrient Intakes and Physical Measurements; Australian Bureau of Statistics: Canberra, Australia, 1998; ISBN 0642257248.

73. Williams, P.G. Breakfast and the diets of Australian adults: An analysis of data from the 1995 National Nutrition Survey. Int. J. Food Sci. Nutr. 2005, 56, 65-79. [CrossRef] [PubMed]

74. Rangan, A.M.; Samman, S. Zinc intake and its dietary sources: Results of the 2007 Australian national children's nutrition and physical activity survey. Nutrients 2012, 4, 611-624. [CrossRef] [PubMed] 
75. Pasiakos, S.M.; Agarwal, S.; Lieberman, H.R.; Fulgoni, V.L. Sources and amounts of animal, dairy, and plant protein intake of US adults in 2007-2010. Nutrients 2015, 7, 7058-7069. [CrossRef] [PubMed]

76. Drewnowski, A. Concept of a nutritious food: toward a nutrient density score1-3. Am. J. Clin. Nutr. 2005, 82, 721-732. [CrossRef] [PubMed]

77. Hansen, R.G.; Wyse, B.W.; Sorenson, A.W. Nutritional Quality Index of Foods; AVI Publishing Co. Inc.: Westport, CT, USA, 1979; ISBN 0870553208.

78. Sorenson, A.W.; Wyse, B.W.; Wittwer, A.J.; Hansen, R.G. An index of nutritional quality for a balanced diet. New help for an old problem. J. Am. Diet. Assoc. 1976, 68, 236-242. [PubMed]

79. Garlick, P. The role of leucine in the regulation of protein metabolism. J. Nutr. 2005, 135, 1553S-1556S. [CrossRef] [PubMed]

80. Volpi, E.; Kobayashi, H.; Sheffield-Moore, M.; Mittendorfer, B.; Wolfe, R.R. Essential amino acids are primarily responsible for the amino acid stimulation of muscle protein anabolism in healthy elderly adults. Am. J. Clin. Nutr. 2003, 78, 250-258. [CrossRef] [PubMed]

81. Blomstrand, E.; Eliasson, J.; Karlsson, H.K.R.; Köhnke, R. Branched-chain amino acids activate key enzymes in protein synthesis after physical exercise. J. Nutr. 2006, 136, 269S-273S. [CrossRef] [PubMed]

82. Xu, Z.; Mcclure, S.; Appel, L. Dietary cholesterol intake and sources among U.S adults: Results from national health and nutrition examination surveys (NHANES), 2001-2014. Nutrients 2018, 10, 771. [CrossRef] [PubMed]

83. Hoffman, J.R.; Falvo, M.J. Protein - Which is best? J. Sport. Sci. Med. 2004, 3, 118-130.

84. Keast, D.R.; Fulgoni, V.L.; Nicklas, T.A.; O'Neil, C.E. Food sources of energy and nutrients among children in the United States: National health and nutrition examination survey 2003-2006. Nutrients 2013, 5, $283-301$. [CrossRef] [PubMed]

85. Hunt, J.R. Biaoavailability of iron, zinc, and other trace minerals from vegetarian diets. Am. J. Clin. Nutr. 2003, 78, 633S-639S. [CrossRef] [PubMed]

86. Tidemann-Andersen, I.; Acham, H.; Maage, A.; Malde, M.K. Iron and zinc content of selected foods in the diet of schoolchildren in Kumi district, east of Uganda: a cross-sectional study. Nutr. J. 2011, 10, 81. [CrossRef] [PubMed]

87. Wu, G.; Fanzo, J.; Miller, D.D.; Pingali, P.; Post, M.; Steiner, J.L.; Thalacker-Mercer, A.E. Production and supply of high-quality food protein for human consumption: Sustainability, challenges, and innovations. Ann. N. Y. Acad. Sci. 2014, 1321, 1-19. [CrossRef] [PubMed]

88. Gallagher, C.M.; Black, L.J.; Oddy, W.H. Micronutrient intakes from food and supplements in Australian adolescents. Nutrients 2014, 6, 342-354. [CrossRef] [PubMed]

89. Lim, K.H.C.; Riddell, L.J.; Nowson, C.A.; Booth, A.O.; Szymlek-Gay, E.A. Iron and zinc nutrition in the economically-developed world: A review. Nutrients 2013, 5, 3184-3211. [CrossRef] [PubMed]

90. Hansen, R.G. An index of food quality. Nutr. Rev. 1973, 31, 1-7. [CrossRef] [PubMed]

91. Diet, Nutrition and the Prevention of Chronic Diseases. Report of a Joint WHO/FAO Expert Consultation; WHO Techni: Geneva, Switzerland, 2003; ISBN 924120916X.

92. He, F.J.; Li, J.; Macgregor, G.A. Effect of longer term modest salt reduction on blood pressure: Cochrane systematic review and meta-analysis of randomised trials. BMJ 2013, 346, f1325. [CrossRef] [PubMed]

93. O'Neil, C.E.; Nicklas, T.A.; Zanovec, M.; Cho, S. Whole-grain consumption is associated with diet quality and nutrient intake in adults: The national health and nutrition examination survey, 1999-2004. J. Am. Diet Assoc. 2010, 110, 1461-1468. [CrossRef] [PubMed]

(C) 2019 by the authors. Licensee MDPI, Basel, Switzerland. This article is an open access article distributed under the terms and conditions of the Creative Commons Attribution (CC BY) license (http://creativecommons.org/licenses/by/4.0/). 